\title{
Association between lactoferrin single nucleotide polymorphisms and milk production traits in Polish Holstein cattle
}

\author{
Adrianna Pawlik, Grazyna Sender, Magdalena Sobczynska, Agnieszka Korwin- \\ Kossakowska, Jolanta Oprzadek and Marek Lukaszewicz \\ Institute of Genetics and Animal Breeding of the Polish Academy of Sciences, Jastrzębiec, Poland
}

\begin{abstract}
Bovine lactoferrin exhibits strong potential for further applications as a mastitis resistance marker. Since selection for mastitis resistance should not interfere with dairy performance, we investigated the association between bovine lactoferrin gene polymorphism and production traits in Polish Holsteins. The associations between four SNPs, localized in the $5^{\prime}$-flanking region and in exons 4 and 9 of the lactoferrin gene, and dairy performance were examined. SNPs were associated with almost all test-day milk performance traits. Significant associations were found between lactoferrin genotypes and the estimated breeding values for those traits. To find out whether the discrepancies between the lactoferrin gene SNP's influence on phenotype (test-day milk performance) and on estimated breeding values originate from the impact of other factors, we explored the genotype by environment interaction. Substantial impacts of SCC, lactation stage and parity were found. This paper suggests that the genotype by environment interaction may significantly change associations between genes and traits. It is important to include similar analyses to the studies on disease markers before using them in the selection.
\end{abstract}

Keywords: mastitis marker; lactoferrin gene; estimated breeding values; milk performance traits

\begin{abstract}
Abbreviations: DIM: days in milk; EBV: estimated breeding value; GLM: general linear model; HWE: Hardy-Weinberg equilibrium; LF: lactoferrin; LS: least squares; SCC: somatic cell count; SCS: somatic cell score; SNP: single nucleotid polymorphism
\end{abstract}

Archiv Tierzucht 57 (2014) 27, 1-12

doi: $10.7482 / 0003-9438-57-027$

Corresponding author:

Grazyna Sender; email: g.sender@ighz.pl

Institute of Genetics and Animal Breeding of the Polish Academy of Sciences, Jastrzębiec, ul. Postepu 1, 05-552 Magdalenka, Poland

(C) 2014 by the authors; licensee Leibniz Institute for Farm Animal Biology (FBN), Dummerstorf, Germany. This is an Open Access article distributed under the terms and conditions of the Creative Commons Attribution 3.0 License (http://creativecommons.org/licenses/by/3.0/).
Received: 21 February 2014 Accepted: 15 Juli 2014 Online: एOctober 2014 


\section{Introduction}

Genetic variance in dairy performance traits in cattle has been explored for more than 20 years now, giving not much more than a few QTLs strongly associated with the traits of interest. ABCG2, DGAT1 CASB, IGF2 and GHR genes are among these exceptions, but not without inconsistency in the results (Komisarek et al., 2004, Bagnicka et al., 2010, Olsen et al., 2007, Olenski et al., 2012, 2010). It has been shown that genes, connected originally to health and development traits, like IL8, IL8R, CCL2, CCR2, can be associated with dairy performance. Polymorphisms found in the above-mentioned genes are connected to at least one of the five main performance traits: milk, protein and fat yield, protein and fat percentage (LeyvaBaca et al. 2007, Chen et al. 2010, Sanz et al. 2010). Lactoferrin (LF), an iron-chelating protein, is present in many mammalian biological fluids, including milk. Lactoferrin is a potential genetic marker for mastitis resistance, due to the following reasons: this protein plays a crucial role in immune response during mastitis (e.g. Rainard \& Riollet 2005); the magnitude of its expression is connected to the udder health state (e.g. Chen \& Mao 2004); and, importantly, the LF gene and its promoter are highly polymorphic. SNPs localized within the LF gene and its 5 ' regulatory regions have been investigated with reference to gene expression and disease susceptibility (see review by Pawlik et al. 2009). It was found that LF SNPs are connected to the somatic cell count (SCC) or score (SCS) (O'Halloran et al. 2010, Sender et al. 2010), and SNPs in the $5^{\prime}$-regulatory region are connected to LF expression (unpublished data). Since LF exhibits potential for further application as a mastitis resistance/susceptibility marker and selection for mastitis resistance cannot interfere with selection for dairy performance (which would diminish milk production profitability) there is a need to evaluate whether LF is associated with dairy performance traits. The unfavourable effect of LF on milk traits may possibly make it an inferior mastitis marker.

Only a few papers have so far included bovine chromosome 22 (in which the LF gene is localized) among the regions of importance for milk traits (Ashwell et al. 2004, Kolbehdari et al. 2009). There are, however, reports that the LF genotype influences dairy performance, apart from its impact on SCC (Kamiński et al. 2006, O'Halloran et al. 2010).

It is known that genetic merit for traits of animal health and reproduction is in opposition to merit for production traits. Thus, it is of great importance to discover associations between genes related with animal health and performance simultaneously. Other genes, like IGFI and LF "ancestor gene" - TF, were proved to influence milk performance, despite their primary role in health, development or reproduction (Sanz et al. 2010, Szewczuk et al. 2012). This suggests the pleiotropic effect, or the existence of a linkage between genes coding for the non-productive traits and dairy performance traits.

Due to the above-mentioned facts, the aim of this paper was to investigate the associations between four SNPs, localized within the LF gene and its $5^{\prime}$-flanking region, and dairy performance traits. To achieve this, LF genotype impact on the phenotypic values of milk traits was evaluated. To carry out an in-depth analysis of LF genotype impact on the traits of interest, genotype $\times$ environment interactions analysis was performed. Finally, the influence of the genotype on estimated breeding values (EBV) for those traits was investigated. 


\section{Material and methods}

Animals

Lactoferrin gene genotypes were determined for 480 Polish Holsteins cows - daughters of 165 sires from one herd. Performance data were scored in an official milk recording system. Milk samples were collected between 1998 and 2011. Test day milk yield, milk protein and fat yields, as well as protein and fat percentages were taken into account. Animals were in their 1st to 8th lactation. The number of animals was lowered with the subsequent parities. Samples were taken from 473 animals in the 1st lactation, 374 in the 2nd, 216 in the 3rd, 104 in the 4 th and 36 in the 5 th to 8 th lactations.

\section{Genotyping}

The LF gene SNPs used in this study were previously described by Seyfert et al. (1994) and Li et al. (2004). Two SNPs were located in the $5^{\prime}$-flanking region of the LF gene: G/A at position -926 (in this paper: »LF-926«) and G/C at the +32 position (the $5^{\prime}-U T R$ region, here: »LF+32«). SNP at the +32 position was previously called +33 by some authors (Li et al. 2004). Two other SNPs were placed in the LF gene exons: non-synonymous SNP A/G (ILE/VAL) in exon 4 (rs109741625, here: »LFex4«) and synonymous SNP C/T in exon 9 (rs43765461, in this paper: »LFex9«).

The DNA was extracted from blood by the method according to Kanai et al. (1994). Primers used in the PCR reactions for the amplification of the three SNPs: LF-926, LFex4 and LFex9 were taken from the paper by Li et al. (2004). Primers for the amplification of the fragment containing LF+32 SNP were designed with the use of Primer3 software (Untergrasser et al. 2012; http://bioinfo.ut.ee/primer3) and were (5'-3'): TTT CTC GCT CCC TCG GTC T (fwd) and CCC CGC CCC CAC TCA TAC (rev). Webcutter 2.0 software (http://rna.lundberg.gu.se/cutter2/) was used for restriction enzyme selection. RFLP reaction was done with the use of Fermentas nucleases (Thermo Fisher Scientific, Waltham, MA, USA) according to the manufacturer's recommendations. The restriction enzymes used in the study were as follows: LF-926: Faql, LF+32: Eco0109I, LFex4: Mbol, LFex9: Eco81l. Agarose gel electrophoresis bands, obtained for each allele, measured: LF-926: A: 229bp, G: 168 and 61bp; LF+32: C: 264, 166 and 56bp, G: 430 and 56bp; LFex4: A: 117 and 78bp, G: 195 bp; LFex9: C: 159bp, T: 103 and 56bp.

\section{Statistical analysis}

Association between the LF genotype and milk performance traits

The analysis of variance for the estimation of the LF gene polymorphism effect upon dairy performance traits was performed with 14045 test day observations. Traits chosen for the analysis were: test-day milk yield, protein and fat yields, and protein and fat percentages. The classification used for the analysis of the association between LF SNP polymorphism and dairy performance included the fixed effects of the LF genotype, animal nested in LF genotype, yearXseason of calving interaction (55 levels - starting from the 1st quarter of 1998), parity (5 levels - 6 th and subsequent lactations were included in the 5 th) and linear regression on days in milk (DIM). Differences between animals carrying a particular LF genotype were tested for significance with Tukey range test in the GLM procedure (SAS Software). The exact test (ALLELE procedure in SAS Software v 9.1, SAS Institute Inc., Cary, NC, USA) tested deviation from the Hardy-Weinberg equilibrium (HWE). 
Genotype by environment interaction

An effect of the genotypexenvironment interaction was added to the above described model. If genotypexenvironment interaction was significant, performances observed for different genotypes were categorized and the differences between them were analysed. The significance of LF genotype impact on milk performance was investigated for subsequent parities: 1st, 2nd and 3rd (later lactations were included in the 3rd parity) (respectively 473, 374 and 216 animals), different lactation stages (DIM: 5-30, 31-250, >250, respectively 467, 477 and 434 animals) and SCC $>$ or $<200000$ per $\mathrm{ml}$ (respectively 470 and 461 animals). For example, if genotypexlactation stage interaction significantly influenced milk yield, the differences in milk yield between the individuals carrying particular LF genotypes were tested for significance with Tukey range test in the GLM procedure in different lactation stages.

Association between LF genotype and the animal EBV for milk traits

Animal EBVs for milk traits were estimated by the authors for the 480 cows described earlier. The pedigree information spanned two generations. The variance components of test-day milk recordings were estimated by the REML (restricted maximum likelihood) method using VCE 6.02 software (http://vce.tzv.fal.de) and EBV were estimated by BLUP (best linear unbiased prediction) using PEST software (Groeneveld et al. 2002) by the mixed animal model:

$$
y=X b+Z_{1} a+Z_{2} p e+e
$$

where $y$ is the vector of observations containing the test day results for each of the milk performance traits of each cow (14045 records), vector $b$ represents the fixed effects, including the effects of interaction year×season of calving, lactation number, linear regression on DIM, vector $p$ e represents the permanent environmental effects and vector $\boldsymbol{a}$ denotes the random additive genetic effects. Vector e considers the residual effects. The known incidence matrices $X, Z_{1}, Z_{2}$ relate to observations of the corresponding fixed and random effects.

For 252 dairy cows from the above-mentioned 480, official (according to the Polish Ministry of Agriculture Decree 5/1999) animal life EBV data, with the accuracy range of 0.71, were available. Official EBVs and the EBVs estimated by the authors were used separately to analyse the LF genotype influence on animal EBVs for performance traits. The differences between LF genotypes were tested for significance with Tukey range test in the GLM procedure.

Additive and dominance effects of each SNP on animal EBV for milk performance traits were estimated with the use of the orthogonal contrasts. The dominance effect was assumed to be the difference between a solution for heterozygotes and mean solution for the homozygotes.

\section{Results and discussion}

Table 1 shows genotype frequencies for the analysed SNPs. No deviation from HWE was observed for the chosen SNPs, although minor allele frequencies, especially regarding the LF-926 A allele, were very low. 
Table 1

Genotype frequencies for LF gene SNPs in the studied population

\begin{tabular}{lccc}
\hline SNP & Genotype & No of animals & Frequency \\
\hline LF-926 & AA & 3 & 0.01 \\
& AG & 56 & 0.12 \\
LF+32 & GG & 410 & 0.87 \\
& CC & 19 & 0.04 \\
& GC & 130 & 0.27 \\
LFex4 & GG & 326 & 0.69 \\
& AA & 284 & 0.60 \\
& AG & 175 & 0.37 \\
LFex9 & GG & 16 & 0.03 \\
& CC & 22 & 0.04 \\
& CT & 151 & 0.32 \\
& TT & 306 & 0.64 \\
\hline
\end{tabular}

Test day LS means for milk performance traits are presented in Table 2. Each SNP was connected to at least one of the traits. All four SNPs influenced fat yield, but only one (LF+32) was associated with fat percentage. The most favourable genotypes in the context of the dairy performance were: LFex9 TT, LF+32 GG and LFex4 AA.

Table 2

Test day LS means (and SE) for milk performance traits in cows carrying different LF genotypes (G)

\begin{tabular}{|c|c|c|c|c|c|c|c|c|c|c|c|}
\hline SNP & G & Milk, kg & SE & Protein, kg & SE & Protein, \% & SE & Fat, kg & SE & Fat, $\%$ & SE \\
\hline \multirow[t]{3}{*}{ LF-926 } & $A A$ & 26.02 & 2.82 & 0.90 & 0.10 & $3.93^{c^{*}}$ & 0.38 & $0.7^{\mathrm{AB}}$ & 0.12 & 3.34 & 0.48 \\
\hline & AG & 25.98 & 0.96 & 0.81 & 0.03 & 3.40 & 0.13 & $0.93^{\mathrm{A}}$ & 0.04 & 3.60 & 0.16 \\
\hline & GG & 26.47 & 1.19 & 0.84 & 0.04 & $3.44^{c}$ & 0.16 & $0.93^{\mathrm{B}}$ & 0.05 & 3.57 & 0.20 \\
\hline \multirow[t]{3}{*}{$L F+32$} & $\mathrm{CC}$ & $24.38^{\mathrm{GH}}$ & 1.43 & $0.79^{\mathrm{jk}}$ & 0.05 & 3.44 & 0.19 & $0.80^{1 J}$ & 0.06 & $3.32^{x}$ & 0.24 \\
\hline & $\mathrm{GC}$ & $26.42^{\mathrm{G}}$ & 1.18 & $0.84^{j}$ & 0.04 & 3.44 & 0.16 & $0.91^{\mathrm{lb}}$ & 0.05 & 3.53 & 0.20 \\
\hline & GG & $26.65^{\mathrm{H}}$ & 1.19 & $0.84^{k}$ & 0.04 & 3.45 & 0.16 & $0.93^{\mathrm{Jb}}$ & 0.05 & $3.60^{x}$ & 0.20 \\
\hline \multirow[t]{3}{*}{ LFex4 } & $\mathrm{AA}$ & $27.01^{\mathrm{F}}$ & 1.21 & $0.86^{\mathrm{R}}$ & 0.04 & $3.47^{\mathrm{H}}$ & 0.16 & $0.94^{\mathrm{hG}}$ & 0.05 & 3.57 & 0.20 \\
\hline & AG & $25.94^{\mathrm{F}}$ & 1.19 & $0.82^{R}$ & 0.04 & $3.43^{k}$ & 0.16 & $0.91^{\mathrm{Dh}}$ & 0.05 & 3.57 & 0.20 \\
\hline & GG & $22.16^{\mathrm{F}}$ & 1.12 & $0.72^{\mathrm{R}}$ & 0.04 & $3.30^{\mathrm{Hk}}$ & 0.15 & $0.82^{\mathrm{GD}}$ & 0.05 & 3.60 & 0.19 \\
\hline \multirow[t]{3}{*}{ LFex9 } & $\mathrm{CC}$ & $23.22^{\mathrm{B}}$ & 1.30 & $0.76^{\mathrm{M}}$ & 0.04 & 3.37 & 0.18 & $0.80^{v z}$ & 0.06 & 3.48 & 0.22 \\
\hline & $\mathrm{CT}$ & $25.75^{\mathrm{B}}$ & 1.08 & $0.81^{\mathrm{M}}$ & 0.04 & 3.40 & 0.15 & $0.91^{\mathrm{vz}}$ & 0.05 & 3.58 & 0.18 \\
\hline & $\mathrm{TT}$ & $27.03^{B}$ & 1.23 & $0.86^{\mathrm{M}}$ & 0.04 & 3.48 & 0.17 & $0.94^{\mathrm{Zz}}$ & 0.05 & 3.57 & 0.21 \\
\hline
\end{tabular}

Means marked in bold and by the same upper-case letter differ at $\mathrm{P}<0.01$; marked with the same lower-case letter differ at $\mathrm{P}<0.05$

The significance of the genotype by environment interactions are shown in the Tables 3 , 4 and 5. Lactoferrin gene variants' influence on milk performance traits was significantly altered by the lactation stage (Table 3). The associations between: LF-926 and LFex9 and milk yield, LFex9 and protein yield, LFex4 and LFex9 and protein and fat percentages, as well as fat yield depended on the stage of lactation. Figure 1 presents an example of a significant interaction: LFex4 genotypes influence fat percentage in different ways, according to the lactation stage. The highest fat percentage was observed in the milk of cows carrying the 
GG genotype in early lactation, but not in full or late lactation. The SCC class was the factor that modified the association between the LFex9 genotype and milk and protein yield, as well as the associations between LFex4 and Lfex 9 genotype and protein and fat percentage (Table 4). An example chart is shown in Figure 2: the LFex9 genotype is associated with the fat percentage with the influence of the SCC. The highest fat percentage was observed in healthy cows $\left(\mathrm{SCC}<200000^{*} \mathrm{ml}^{-1}\right)$ with the LFex9 TT genotype, but in cows with subclinical mastitis $\left(\mathrm{SCC}>200000^{*} \mathrm{ml}^{-1}\right)$ that carried the CC genotype. Parity also influenced the LF gene variants' impact on the performance traits (Table 5). The correlations between all four SNPs and protein and fat yield were modified by the age of the cow (parity). Also, the associations between LF gene variants and milk yield were altered by the parity regarding three mutations (excluding LFex4 SNP). Despite the differences in numbers of the observation in each class of the environmental factors (e.g. majority of the cows were in their first lactation, which could have affected the estimation), interactions between LF genotype and environment were significant for most of the performance traits.

Table 3

Significance ( $P$-value) of an interaction between LF genotype and lactation stage (SNPXStage) effects on milk performance traits

\begin{tabular}{|c|c|c|c|c|c|}
\hline Interaction & Milk, kg & Protein, kg & Protein, \% & Fat, kg & Fat, $\%$ \\
\hline LF-926×Stage & 0.0387 & 0.1285 & 0.4386 & 0.2196 & 0.7072 \\
\hline $\mathrm{LF}+32 \times$ Stage & 0.7984 & 0.1154 & 0.2529 & 0.7058 & 0.7058 \\
\hline LFex4×Stage & 0.0853 & 0.1237 & 0.0482 & 0.0109 & 0.0080 \\
\hline LFex9×Stage & 0.0002 & 0.0041 & 0.0367 & 0.0001 & 0.0111 \\
\hline
\end{tabular}

Table 4

Significance ( $p$-value) of an interaction between LF genotype and SCC class (SNP $\times$ SCC) effects on milk performance traits

\begin{tabular}{|c|c|c|c|c|c|}
\hline Interaction & Milk, kg & Protein, kg & Protein, $\%$ & Fat, kg & Fat, $\%$ \\
\hline LF-926×SCC & 0.1738 & 0.2284 & 0.2317 & 0.2072 & 0.0514 \\
\hline $\mathrm{LF}+32 \times \mathrm{SCC}$ & 0.2064 & 0.2047 & 0.7089 & 0.8760 & 0.8073 \\
\hline LFex $4 \times$ SCC & 0.1205 & 0.0702 & 0.0014 & 0.5093 & 0.0333 \\
\hline LFex9×SCC & 0.0421 & 0.0126 & 0.0042 & 0.0523 & 0.0043 \\
\hline
\end{tabular}

Table 5

Significance ( $P$-value) of an interaction between LF genotype and parity (SNP $\times$ parity) effects on milk performance traits

\begin{tabular}{|c|c|c|c|c|c|}
\hline Interaction & Milk, kg & Protein, kg & Protein, \% & Fat, kg & Fat, $\%$ \\
\hline LF-926×parity & 0.0001 & 0.0205 & 0.0629 & 0.0019 & 0.0944 \\
\hline LF+32×parity & 0.0006 & 0.0099 & 0.1128 & 0.0002 & 0.1982 \\
\hline LFex4×parity & 0.0574 & 0.0389 & 0.2069 & 0.0066 & 0.0960 \\
\hline LFex9×parity & 0.0003 & 0.0168 & 0.3013 & 0.0028 & 0.3159 \\
\hline
\end{tabular}

Animal EBVs for the milk performance traits in cows carrying different LF genotypes are shown in Table 6. Results obtained with phenotypic values were compared with the animal EBVs for the corresponding traits. It was observed that the favourable effects of the LFex9 genotype TT on animal EBV correspond with phenotypic values for all three milk performance traits (the highest: milk yield, protein and fat yield). The effects of the LFex4 AA genotype were 

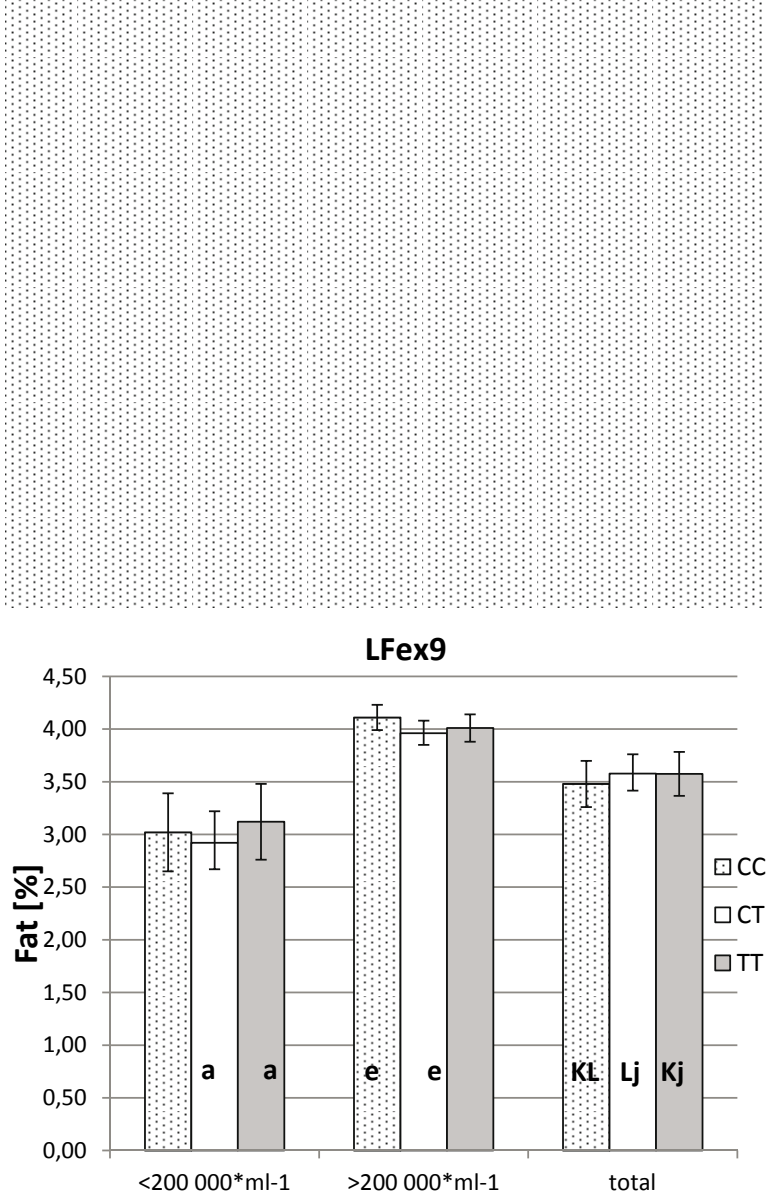

Figure 1

An example of genotype by environment interaction: the influence of LFex4 SNP on fat percentage in different stages of lactation and in whole lactation (total) (Means marked by the same upper-case letter differ at $P<0.01$; marked with the same lower-case letter differ at $P<0.05$ )
Figure 2

An example of genotype by environment interaction: the influence of LFex9 SNP on fat percentage with regard to SCC (threshold value: 200000 cells per ml) (Means marked by the same upper-case letter differ at $P<0.01$; marked with the same lower-case letter differ at $P<0.05$ )

retained for milk and protein yields but not for the fat yield (although a significant difference in milk fat percentage between LFex4 AA and GG genotypes was observed). The effects of the genotypes' influence on milk yield, protein and fat yields are in accordance with the wellknown genetic and phenotypic correlations between those traits (Van Vleck \& Dong 1988). Therefore, when SNP is positively associated with milk yield it is also positively associated with protein yield. LF-926 and LF+32 genotypes were associated only with animal EBV for fat yield, whereas LFex4 and LFex9 genotypes were associated with milk yield, protein yield and either fat yield (LFex9) or fat percentage (LFex4).

The official EBVs for the milk performance traits carrying different LF genotypes are shown in Table 7. The favourable effect of three genotypes: AG (LF-926) as well as GG (LF+32) on fat yield, and AA (LFex4) on milk yield were confirmed by the analysis based on official EBVs, despite the small number of animals used in the variance analysis (due to the limited availability of official data).

It has been shown that the interrelationships between animal EBV and LF genotype reflect, but only to a limited extent, the associations between the analysed SNPs and milk performance phenotypic value. This can be caused either by the sample size, by the low 

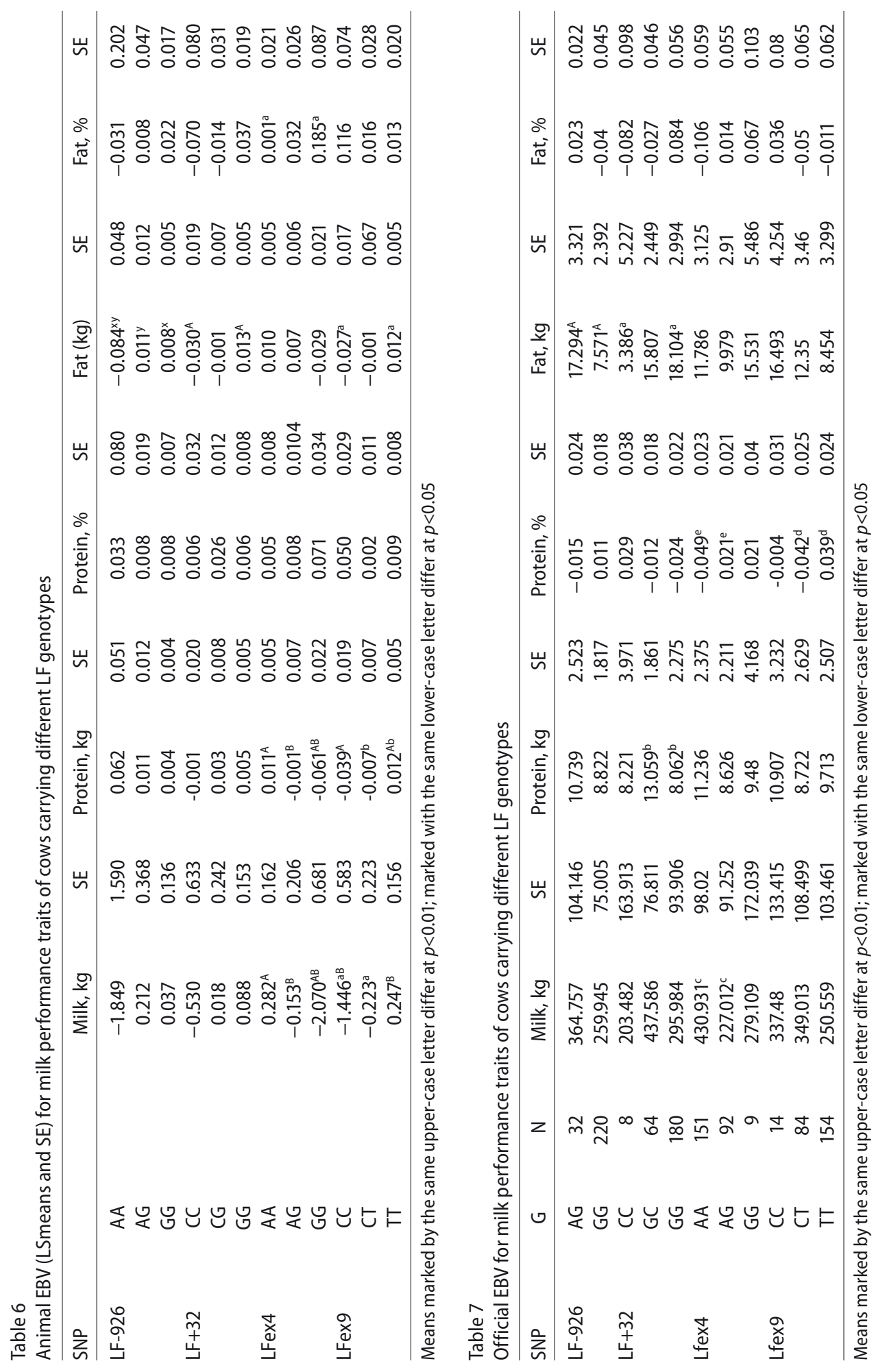
accuracy of the animal EBV prediction, or by the environmental impact on the animal genome expression. We speculate that the basis of the observed divergence in our population lies in the latter, as the analysis of environmental factors has shown that they significantly influence the relationship between LF SNPs and dairy performance.

We found that the »re-ranging " of LF genotype's influence on milk production traits occurs when cows are suffering from subclinical mastitis (SCC>200000 per ml). Moreover, it shows up in successive parities, and even within the particular lactation (effects of the genotypes on milk traits change with DIM). It is not common to use factors like those used in our study (lactation stage, parity, SCC class) to evaluate genotypexenvironment interaction's effect on milk performance. The main environmental factors analysed so far included: feeding system (Kearney et al. 2004), reproduction-related factors (Haile-Mariam et al. 2008) or the geographic environment (Hammami et al. 2009). To our knowledge, an exclusive analysis, where the parity was included as a factor that influenced associations between LF genotype and health, was made by Wojdak-Maksymiec et al. (2013). The above-mentioned authors found that parity remarkably influences LF genotype impact on mastitis susceptibility.

The additive and dominance effects in each of four LF loci were estimated. No dominance effect was observed for any of the SNPs and additive effects were significant only considering milk and protein yields for LFex4 and LFex9 SNPs, fat yield for LF-926, LF+32 and LFex9 SNPs and fat percentage for LFex4 SNP. Summing up the results, we found that the most favourable lactoferrin genotypes in the context of dairy performance are: LF-926 GG, LF+32 GG and GC, LFex4 AA, LFex9 TT.

The relationship between LF SNPs and animal EBV is cleared from the environmental impact, therefore we suspect that LF-926, LF+32 and LFex4 SNPs are the most promising SNPs regarding their associations with dairy preformance.

The result which is worth highlighting is LFex4 polymorphism's influence on the milk traits. The association between genotype and milk yield is neither violated by the lactation stage, nor by the other two environmental factors analysed in this study. Moreover, the favourable effect of LFex4 AA genotype was retained with the official EBV data used for the estimation.

The pleiotropic effect of LF gene variants on functional and performance traits was studied previously by other groups (Zabolewicz et al. 2012, O'Halloran et al. 2010, Kaminski et al. 2006). Zabolewicz et al. (2012) analysed SNP, located in the LF gene TATA box (in position: 5':-28), but found no statistically significant influence of lactoferrin genotype on milk performance in Polish Holsteins. The same polymorphism, along with two others, localized in the promoter region (in positions: -586 , and -190 ) was investigated by O'Halloran et al. (2010). None of the three polymorphisms were associated with the Daughter Yield Deviations (DYD) for any of the dairy performance traits (milk yield, fat yield, protein yield). O'Halloran et al. (2010) carried out an additional analysis, in which they included genotype as a class effect and found a significant association of LF-28 SNP with milk yield and protein yield. On the other hand, significant associations of bovine LF gene with milk traits were also found and were described in the two following papers (Kaminski et al. 2006 and Sender et al. 2007). The results of Kaminski et al. (2006) regarding LF+32 SNP were contrary to those presented in this paper (they found LF+32 genotype CC to be the most favourable), but the authors based their deduction on the phenotypic values of milk performance traits only. Such analysis can display a fake picture of the animal genetic effect. A study conducted by Sender et al. (2007) showed 
a significant interrelationship between one of the intronic variants of the LF gene and the milk yield of 516 Polish Holsteins (phenotypic value). Discrepancies in the results obtained by different groups may come from different statistical models used for the evaluations (e.g. underestimation of other effects, like genotype by environment interaction), or the usage of phenotypic data without the animal EBV information. They may also be a result of the linkage phase between the actual QTLs for performance traits and analysed SNPs in different populations. Moreover, lactoferrin is involved in many physiological processes and possesses multiple activities (eg. Adlerova et al., 2008); the results of experiments, conducted on dairy cows during their lactation may also be influenced by the biological functions of the protein, especially regarding to the analyse of the phenotype

In conclusion, it must be highlighted that the pleiotropic effects of genes coding for functional traits should be taken into account during the analysis of their impact on health (or fitness)-related traits, like mastitis susceptibility. It was shown that each of four genetic variants of LF is associated with at least one of the main dairy performance traits and animal EBV for those traits. The strongest association was observed for LF+32 and LFex4 SNPs, for which associations between genotype and performance traits were observed for both selfestimated and official EBVs.

We would like to highlight the genotype by environment interaction which was described in this study. The results of this study suggest that analyses similar to ours can be helpful for the assessment of genetic markers' usefulness for further selection. This paper asserts a validation of the obtained results regarding age (parity), health (SCC) and lactation stage, as genotype by environment interaction significantly changes associations between genes and corresponding traits, which was hereby shown.

\section{Acknowledgements}

This work was supported by the Polish National Science Centre, Project Nos. N N311311535, and 2011/01/N/NZ9/00567.

\section{References}

Adlerova L., Bartoskova A, Faldyna, M. (2008) Lactoferrin: a review. Vet-Med Czech 7, 457-468

Ashwell MS, Heyen DW, Sonstegard TS, Van Tassell CP, Da Y, VanRaden PM, Ron M, Weller Jl, Lewin HA (2004) Detection of quantitative trait loci affecting milk production, health, and reproductive traits in Holstein cattle. J Dairy Sci 87(2), 468-475

Bagnicka E, Siadkowska E, Żelazowska B, Flisikowski, Krzyżewski J, Zwierzchowski L (2010). Association of polymorphisms in exons 2 and 10 of the insulin-like growth factor 2 (IGF2) gene with milk production traits in Polish Holstein-Friesian cattle. J Dairy Res 77, 37-42

Chen R, Yang Z, Ji D, Mao Y, Chen Y, Li Y, Wu H, Wang X, Chang L (2010) Polymorphisms of the IL8 gene correlate with milking traits, SCS and mRNA level in Chinese Holstein. Mol Biol Rep 38(6), 4083-4088

Chen P, Mao FC (2004) Detection of lactoferrin in bovine and goat milk by enzyme-linked immunosorbent assay. J Food Drug Anal 12(2), 133-139

Groeneveld E, Kovac M, Wang T (2002) PEST User's Guide and Reference Manual. Version 4.2.3. Department of Animal Sciences University of Illinois

Haile-Mariam M, Carrick M J, Goddard ME (2008) Genotype by environment interaction for fertility, survival, and milk production traits in Australian dairy cattle. J Dairy Sci 91(12), 4840-4853 
Hammami H, Rekik B, Bastin C, Soyeurt H, Bormann J, Stoll J, Gengler N (2009) Environmental sensitivity for milk yield in Luxembourg and Tunisian Holsteins by herd management level. J Dairy Sci 92(9), 4604-4612

Kaminski S, Oleński K, Brym P, Malewski T, Sazanov AA (2006) Single nucleotide polymorphism in the promoter region of the lactoferrin gene and its associations with milk performance traits in Polish Holstein-Friesian cows. Russ J Genet 42(8), 924-927

Kanai N, Fujii T, Saito K, Yokoyama T (1994) Rapid and simple method for preparation of genomic DNA from easily obtained clotted blood. J Clin Pathol 47 1043-1044

Kearney JF, Schutz MM, Boettcher PJ, Weigel KA (2004) Genotype x environment interaction for grazing versus confinement. I. Production traits. J Dairy Sci 87(2), 501-509

Kolbehdari D, Wang Z, Grant JR, Murdoch B, Prasad A, Xiu Z, Marques E, Stothard P, Moore SS (2009) A whole genome scan to map QTL for milk production traits and somatic cell score in Canadian Holstein bulls. J Anim Breed Genet 126(3), 216-227

Komisarek J, Waśkowicz K, Michalak A, Dorynek Z (2004) Effects of DGAT1 variants on milk production traits in Jersey cattle. Anim Sci Pap Rep 22(3), 307-313

Leyva-Baca I, Schenkel F, Sharma BS, Jansen G B, Karrow NA (2007) Identification of single nucleotide polymorphisms in the bovine CCL2, IL8, CCR2 and IL8RA genes and their association with health and production in Canadian Holsteins. Anim Genet 38(3), 198-202

Li GH, Zhang Y, Sun DX, Li N (2004) Study on the polymorphism of bovine lactoferrin gene and its relationship with mastitis. Anim Biotech15, 67-76

O'Halloran F, Berry DP, Bahar B, Howard DJ, Sweeney T, Giblin L (2010) Polymorphisms in the bovine lactoferrin promoter are associated with reproductive performance and somatic cell count. J Dairy Sci 93(3), 12531259

Oleński K, Cieślińska A, Suchocki T (2012) Polymorphism in coding and regulatory sequences of beta-casein gene is associated with milk production traits in Holstein-Friesian cattle Anim Sci Pap Rep 30(1), 5-12.

Oleński K, Suchocki T, Kamiński S (2010) Inconsistency of associations between growth hormone receptor gene polymorphism and milk performance traits in Polish Holstein-Friesian cows and bulls, Anim Sci Pap Rep 28(3), 229-234.I

Olsen HG, Nilsen H, Hayes B, Berg PR, Svendsen M, Lien S, Meuwissen T (2007) Genetic support for a quantitative trait nucleotide in the $A B C G 2$ gene affecting milk composition of dairy cattle. BMC Genetics 8, 32

Pawlik A, Sender G, Korwin-Kossakowska A(2009) Bovine lactoferrin gene polymorphism and expression in relation to mastitis resistance - a review. Anim Sci Pap Rep 27 263-271

Polish Ministry of Agriculture (1999) Regulation of the minister of agriculture and food economy. http://prawo. legeo.pl/prawo/rozporzadzenie-ministra-rolnictwa-i-gospodarki-zywnosciowej-z-dnia-5-maja-1999r-w-sprawie-zakresu-i-metod-prowadzenia-oceny-wartosci-uzytkowej-i-hodowlanej-zwierzat-orazsposobu-oznakowania-i/zal3/?on=11.06.1999 [last accessed 22.08.2014]

Rainard $P$, Riollet $C(2005)$ Innate immunity of the bovine mammary gland. Vet Res 37, 369-400

Sanz A, Ordovás L, Serrano C, Zaragoza P, Altarriba J, Rodellar C (2010) A single nucleotide polymorphism in the coding region of bovine transferrin is associated with milk fat yield. Genet Mol Res 9(2), 843-848

Sender G, Dymnicka M, Korwin-Kossakowska A, Gralak B, Arkuszewska E, Łozicki A (2007) Związek polimorfizmu genu laktoferyny z wydajnością mleka krów rasy polskiej holsztyńsko-fryzyjskiej.[Linkage between lactoferrin gene polymorphism and milk yield in Polish HF cattle.] Rocz Nauk Zoot , 3(4),89-94, [In Polish]

Sender G, Pawlik A, Korwin-Kossakowska A, Galal Abdel Hameid K, Sobczyńska M, Oprzadek J, Prusak B (2010) Association of the bovine lactoferrin polymorphism with occurrence of mastitis. Milchwissenschaft 65 , $242-245$

Seyfert HM, Tuckoricz A, Intertahl H, Koczan D, Hobom G (1994) Structure of the bovine lactoferrin - encoding gene and its promoter. Gene 143 265-269

Szewczuk M, Zych S 2012 Association between IGF1R / i16 / Taql and IGF1 / SnaBI polymorphisms and milk production traits in Polish Holstein-Friesian cows. Anim Sci Pap Rep 30(1), 13-24 
Untergrasser A, Cutcutache I, Koressaar T, Ye J, Faircloth BC, Remm M, Rozen SG (2012) Primer3 - new capabilities and interfaces. Nucl Acids Res 40 (15): e115

Van Vleck LD, Dong MC (1988) Genetic (co)variances for milk, fat, and protein yield in Holsteins using an Animal Model. J Dairy Sci 71(11), 3040-3046

Wojdak-Maksymiec K, Szyda J, Strabel T (2013) Parity-dependent association between TNF- $a$ and LTF gene polymorphisms and clinical mastitis in dairy cattle. BMC Vet Res 9, 114

Zabolewicz T, Brym P, Olenski K, Suchocki T, Malewski T, Szyda J, Kaminski S (2012) Polymorphism within TATAbox of bovine lactoferrin gene and its association with performance traits in Holstein cattle. Livest Sci $149(3), 267-274$ 